\title{
Kajian linguistik korpus kuantitatif terhadap variasi ortografis dan kontekstual: Studi kasus untuk anggé/e(n) dan anggo(n) 'pakai' dalam Bahasa Bali *
}

\author{
Gede Primahadi Wijaya RAJEG ${ }^{\text {a }} \&$ I Made RAJEG $^{\text {b }}$ \\ Universitas Udayana, Indonesia

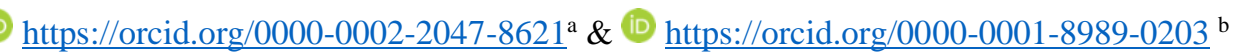

\begin{abstract}
Abstrak
Makalah ini menampilkan suatu studi kasus linguistik korpus kuantitatif terhadap pasangan verba bahasa Bali anggéle( $n)$ dan anggo( $n)$, yang secara semantis leksikal sama-sama berarti 'pakai; gunakan'. Dua aspek yang dikaji meliputi (i) pola ortografis ke(tidak)munculan akhiran nasal pada kedua varian verba yang berbeda vokal akhirnya tersebut, dan (ii) pola kontekstual berdasarkan kolokat khas guna menentukan ragam tingkatan bahasa Bali kedua verba tersebut. Hasil analisis pada aspek pertama menunjukkan asosiasi yang sangat signifikan secara statistik antara jenis vokal akhir dan muncul-tidaknya akhiran nasal yang mengikuti vokal akhir tersebut: anggéle $(n)$ berasosiasi positif dengan akhiran nasal sedangkan anggo berasosiasi negatif dengan akhiran nasal. Hasil analisis aspek kedua mengindikasikan bahwa anggo $(n)$ secara kuat dicirikan oleh kolokat khas dari ragam bahasa Bali andap ('bahasa sehari-hari') sedangkan anggéle( $n$ ) dicirikan oleh kolokat khas dari ragam bahasa Bali alus ('halus'). Hasil kualitaitf dan kuantitatif berdasarkan data korpus seperti ini diharapkan dapat memperkaya deskripsi leksikografis kedua varian verba tersebut.
\end{abstract}

Kata kunci: variasi ortografis, variasi kontekstual, tingkatan bahasa, linguistik korpus kuantitatif, Analisis Kolokat Khas, bahasa Bali

\section{Pengantar}

Makalah ini menganalisis distribusi kuantitatif pola variasi ortografis kata dan konteks pemakaiannya, dalam hal ini kolokasi. Kata target yang dicontohkan adalah pasangan kata kerja bahasa Bali yang mirip secara semantis, yaitu anggon dan anggén, yang sama-sama berarti 'pakai; gunakan'":

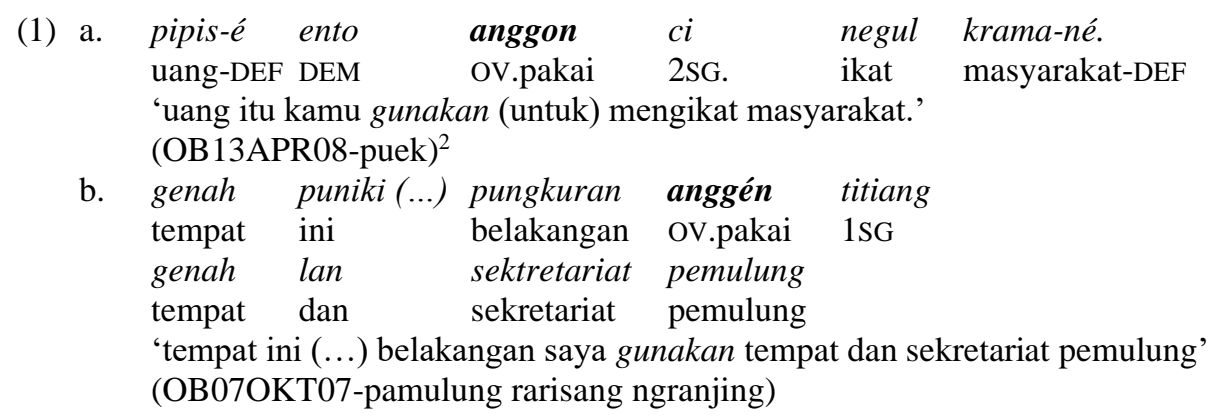

Ciri semantis kedua kata kerja ini juga menarik karena dapat digunakan dan diinterpretasikan sebagai preposisi (lihat (2)a dan b) dengan arti 'untuk (tujuan)'. Hal ini dapat mengindikasikan proses gramatikalisasi anggon dan anggén; gramatikalisasi adalah fenomena melunturnya makna leksikal suatu kata menjadi makna yang lebih umum, seperti makna gramatikal (Hopper \& Traugott 2003):

\footnotetext{
* Atas diskusi dan masukannya, khususnya terkait pembahasan ragam tingkatan bahasa Bali, penulis berterima kasih kepada I Gedé Gita Purnama Arsa Putra (Program Studi Sastra Bali, Fakultas Ilmu Budaya, Universitas Udayana). Semua kekeliruan yang masih terdapat di dalam makalah ini menjadi tanggung jawab penuh penulis.

https://dictionary.basabali.org/w/index.php/Special:RunQuery/Word_search?Word+search\%5BText\%5D=anggo\&title=Sp ecial\%3ASearch\&wpRunQuery=true \&Word+search\%5BLang\%5D=Basa+Bali

2 Komponen di bawah terjemahan contoh kalimat adalah penamaan untuk berkas korpus sumber contoh tersebut. Unsur "OB” dalam korpus berarti 'Orti Bali', yang diikuti oleh tanggal, bulan, tahun, serta judul artikel yang terbit di mingguan Orti Bali.
} 
(2) a. sumpah punika ka-ucap-ang anggén m-(p)ageh-in manah sumpah itu PASS-bilang-TR pakai AV-pagar-APPL pikiran 'sumpah itu diucapkan untuk memagari pikiran' (OB14NOV09-sumpah pejabat sayan-sayan campah)

b. bapa nyadia $m$-(b)eli tanah anggon jalan bapak bersedia AV-beli tanah pakai jalan 'bapak bersedia membeli tanah untuk jalan' (OB29MEI11-sundel tanah)

Kamus daring BASABali Wiki menampilkan dua varian lain kedua kata kerja ini, khususnya varian tanpa bunyi nasal setelah vokal [e] dan [o], yaitu anggo dan angge $e^{3}$. Pada entri anggon dan anggo ${ }^{4}$, BASABali Wiki mengelompokkan anggon dan anggo sebagai varian ragam bahasa Bali kasar; pengelompokan ini tercermin pada contoh-contoh yang ditampilkan untuk anggo(n) pada (1)a dan (2)b, yang unsur leksikalnya mencirikan ragam kasar (mis. pronomina $c i$ 'kamu' pada (1)a). Sedangkan, ketika meng-klik kata terkait dari anggon, yaitu angge, kata tersebut belum memiliki informasi di dalam laman entrinya ${ }^{5}$. Berdasarkan intuisi penulis, varian dengan [é]/[e] mencerminkan ragam bahasa Bali halus. Contoh-contoh untuk varian dengan [é]/[e] pada (1)b dan (2)a menampilkan konteks bahasa Bali halus jika diamati dari kata-kata lain yang muncul dengan anggén pada kedua contoh tersebut. Intuisi ini akan dibuktikan lebih lanjut pada makalah ini dengan melihat kolokasi anggén (lihat Rumusan masalah untuk ulasan lebih rinci).

\section{Rumusan masalah}

Makalah ini memiliki dua rumusan masalah terkait pemaparan pada bagian pengantar sebelumnya. Pertama, adanya varian yang diakhiri ataupun tidak diakhiri bunyi nasal, dan varian perbedaan vokal (yaitu [e] dan [o]) memunculkan pertanyaan terkait apakah variasi ini bersifat acak. Dengan kata lain, apakah muncul-tidaknya akhiran nasal terhadap dua varian bervokal berbeda itu bersifat manasuka?

Atau ada keterkaitan antara akhiran vokal dan muncul-tidaknya akhiran nasal? Keterkaitan antara dua variabel ini (yaitu VOKAL AKHIR [[é/e] dan [o]] dan BUNYI NASAL AKHIR [ya atau tidak]) akan dijawab melalui uji signifikansi Chi-Square test dengan data kuantitatif dari korpus (lihat bagian Data dan metode) (lihat Rajeg \& Rajeg 2019a untuk ulasan Uji Chi-Square dengan data linguistik; untuk tutorial berbahasa Indonesia, lihat Rajeg 2020a).

Rumusan masalah kedua adalah mengeksplorasi kata-kata yang khas (berdasarkan pengukuran statistik) muncul bersama dengan anggéle $(n)$ dan anggo(n) di dalam kalimat; teknik kuantitatif yang digunakan disebut Analisis Kolokat Khas (Distinctive Collocate Analysis [DCA]) (bdk. Gries \& Stefanowitsch 2004; Gries 2013; lihat Rajeg \& Rajeg 2019b untuk penerapan pada data Bahasa Indonesia). Eksplorasi ini bertujuan, salah satunya, menguji secara empiris pencirian anggo $(n)$ dalam BASABali Wiki yang dikelompokkan ke dalam ragam bahasa Bali kasar. Tujuan kedua dari eksplorasi ini adalah untuk memberikan pencirian berdasarkan data korpus (kuantitatif) untuk entri kosong dari angge(n) pada BASABali Wiki.

\section{Data dan metode}

Sumber data makalah ini adalah korpus teks elektronik yang dikumpulkan secara manual dari terbitan mingguan Orti Bali mulai dari tahun 2006 hingga 2013. ${ }^{6}$ Ukuran korpus ini adalah 638,397 kata/token. Untuk menjawab rumusan masalah pertama, kita perlu menghitung frekuensi (i) varian dengan akhiran vokal [é]/[e], yaitu anggén, anggen, anggé, dan angge, dan (ii) varian dengan akhiran vokal [o], yaitu anggon dan anggo (Gambar 1).

\footnotetext{
${ }^{3}$ https://dictionary.basabali.org/Anggon

4 https://dictionary.basabali.org/Anggo

5 https://dictionary.basabali.org/Special:SearchByProperty/Related_to_word/angge

6 Tahun 2013 adalah tahun terakhir laman Orti Bali dapat diakes secara terbuka di laman Bali Post.
} 


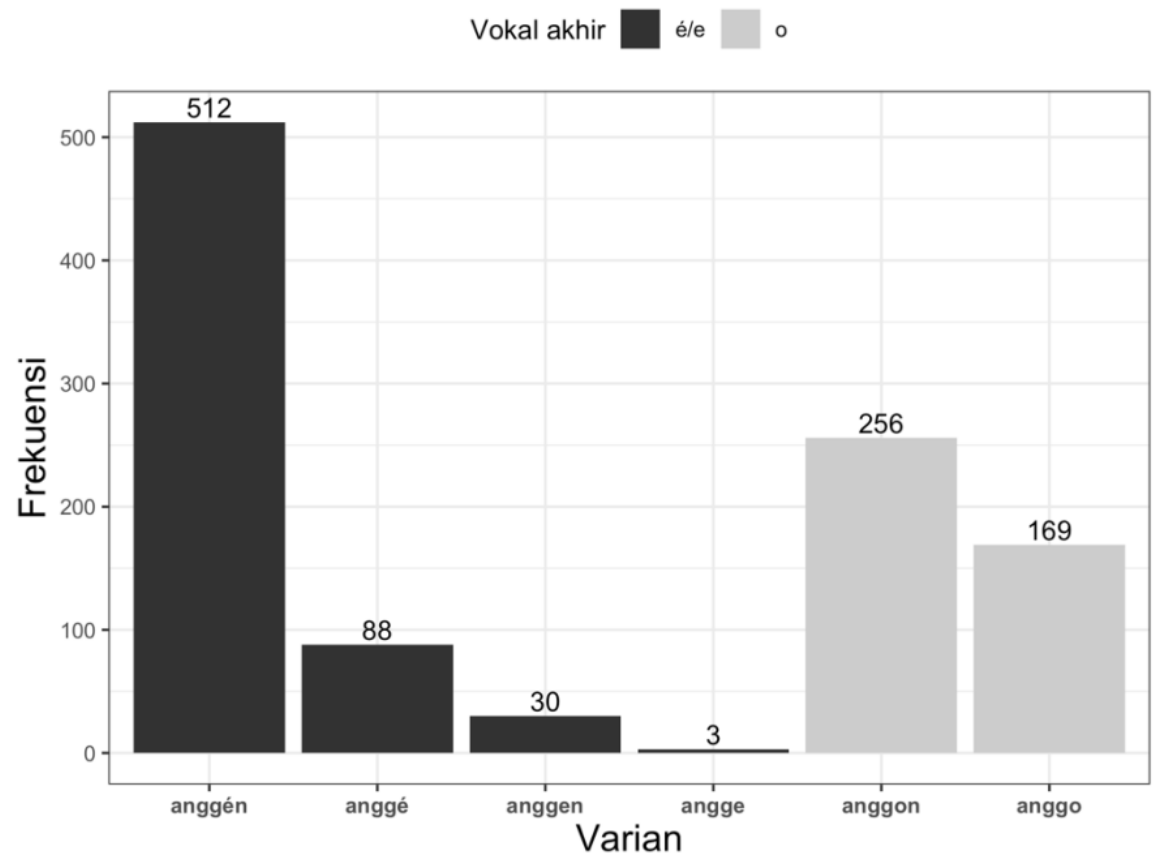

Gambar 1 Frekuensi anggéle(n) dan anggo(n) pada korpus Orti Bali (2006-2013)

Gambar 1 menunjukkan bahwa, secara keseluruhan, varian dengan vokal [é]/[e] secara signifikan memiliki frekuensi lebih tinggi $(\mathrm{N}=633)$ dibandingkan dengan varian bervokal $[\mathrm{o}](\mathrm{N}=425)$ $\left(X_{\text {goodness-of-fit }}^{2}=40.892, d f=1, p<0.001\right)$. Untuk tujuan analisis statistik, frekuensi varian [é] dan [e] digabung dan akan dibandingkan dengan frekuensi varian [o] terkait muncul-tidaknya akhiran nasal [n] setelah kedua vokal tersebut. Selanjutnya, penulis membuat tabulasi silang (crosstabulation) distribusi bentuk dasar dengan varian [é/e] dan [o] dan kemunculannya dengan atau tanpa akhiran nasal. Tabulasi silang ini nantinya akan diuji signifikansinya menggunakan Chi-Square, sekaligus melihat keterkaitan antara akhiran vokal dengan ke(tidak)munculan akhiran nasal. Selain melihat keterkaitan antara varian vokal akhir dengan muncul-tidaknya akhiran nasal pada bentuk dasar anggéle/o(n), keterkaitan dua variabel tersebut juga akan diamati pada bentuk turunannya yang ditemukan dalam korpus (mis. bentuk verba nganggéle/o(n), nomina panganggélelo, dan sejenisnya). Dengan kata lain, jika terdapat asosiasi antara tipe vokal akhir dan muncul-tidaknya akhiran nasal pada bentuk dasar, akankah asosiasi ini dipertahankan pada bentuk turunannya?

Untuk rumusan masalah kedua, yaitu konteks kolokasi dari anggéle/o(n), penulis mengumpulkan frekuensi semua kata-kata yang muncul di sebelah kanan dan kiri (yaitu kolokat) dari kata target, yaitu bentuk dasar anggéle/o(n); penelitian ini membatasi kemunculan kolokat dalam lingkup maksimal tiga kata di sebelah kanan dan kiri dari kata target. Selanjutnya, landasan statistik Analisis Kolokat Khas (DCA) (Gries \& Stefanowitsch 2004; Rajeg \& Rajeg 2019b), yaitu Fisher-Yates Exact (FYE) test, digunakan untuk mengukur kolokat yang khas secara kuantitatif muncul lebih sering daripada yang diharapkan dengan anggéle(n) dibandingkan dengan anggo(n). Analisis kualitatif dari luaran DCA ini ditekankan pada ragam bahasa Bali dari kolokat khasnya: apakah misalnya sebagian besar kolokat khas untuk anggo(n) mencirikan ragam bahasa Bali kasar, seperti yang dijelaskan pada kamus daring BASABali Wiki. Kemudian, bagaimana ciri kolokat khas untuk anggéle(n)?

\section{Hasil dan pembahasan}

Bagian ini melaporkan hasil analisis dan pembahasan kedua rumusan masalah yang dijelaskan sebelumnya. Tahap pengolahan data, analisis statistik, dan visualisasi data semuanya menggunakan peranti pemrograman R (R Core Team 2020). Material pendukung, seperti data dan kode pemrograman R, untuk makalah ini tersedia secara terbuka (lihat Rajeg \& Rajeg 2020, untuk tautan guna mengunduh materi tersebut). 


\section{Distribusi akhiran nasal atas jenis vokal akhir dalam anggé/e(n) dan anggo(n)}

Untuk mengetahui adanya asosiasi antara jenis vokal akhir dan muncul-tidaknya akhiran nasal, kita pertama-tama perlu membuat tabulasi silang frekuensi kemunculan anggéle dan anggo dengan/tanpa akhiran nasal. Tabel 1 menampilkan data tabulasi tersebut, yang dapat secara intuitif dipahami melalui Gambar 2.

Tabel 1 Frekuensi pengamatan (\& persentase) anggéle dan anggo dan ke(tidak)munculan akhiran nasal [n]

\begin{tabular}{|c|c|c|c|}
\cline { 2 - 4 } \multicolumn{1}{c|}{} & \multicolumn{2}{c|}{ AKHIRAN NASAL } & \multirow{2}{*}{ TOTAL } \\
\hline VOKAL AKHIR & Tidak & Ya & $\mathbf{4 2 5}$ \\
\hline o & $169(65 \%)$ & $256(32.08 \%)$ & $\mathbf{6 3 3}$ \\
\hline e/é & $91(35 \%)$ & $542(67.92 \%)$ & $\mathbf{1 0 5 8}$ \\
\hline TOTAL & $\mathbf{2 6 0 ( 1 0 0 \% )}$ & $\mathbf{7 9 8}(\mathbf{1 0 0 \%})$ & \\
\hline \multicolumn{2}{|c|}{ Varian vokal akhir } \\
\hline
\end{tabular}

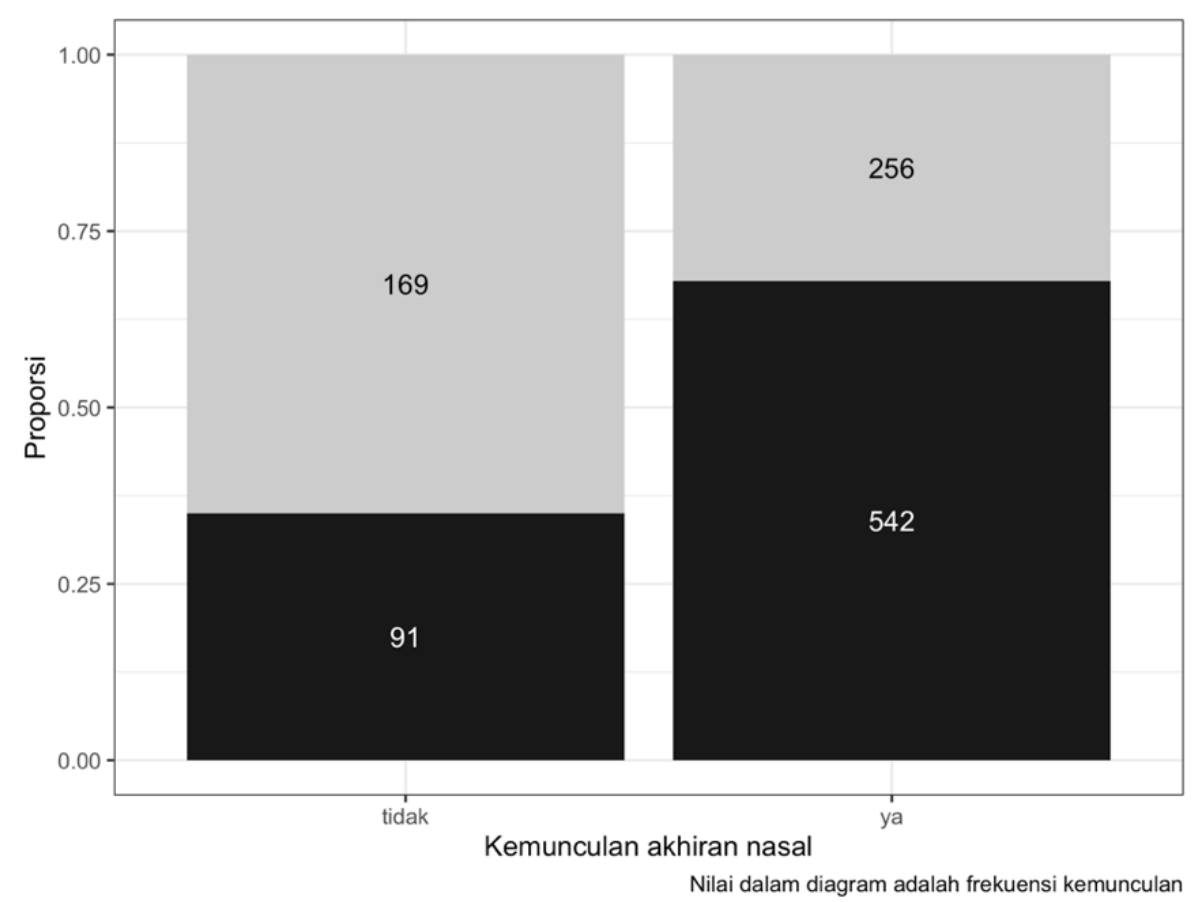

Gambar 2 Frekuensi pengamatan (\& persentase) anggéle dan anggo dan ke(tidak)munculan akhiran nasal [n]

Secara proporsional, Tabel 1 dan Gambar 2 menunjukkan bahwa terdapat perbedaan distribusi akhiran nasal terhadap varian anggéle dan anggo. Proporsi kemunculan anggo dengan akhiran nasal (yaitu anggon; 0.320 atau $32 \%$ ) lebih rendah dibandingkan dengan tanpa akhiran nasal (yaitu anggo; 0.65 atau $65 \%$ ). Sebaliknya, proporsi kemunculan anggéle dengan akhiran nasal (anggé/en) (yaitu 0.679 , atau mendekati 68\%) lebih tinggi daripada tanpa akhiran nasal (anggéle) (yaitu 0.35, atau $35 \%)$.

Uji signifikansi statistik seperti Chi-Square akan dapat menentukan apakah perbedaan distribusi pengamatan pada korpus yang ditampilkan pada Tabel 1 dan Gambar 2 merupakan suatu distribusi yang acak/manasuka/suatu kebetulan sehingga tidak mengindikasikan hubungan antara kedua variabel tersebut (yaitu antara varian vokal dan muncul-tidaknya akhiran nasal)? Ataukah perbedaan distribusi yang diamati terkait ke(tidak)munculan akhiran nasal untuk kedua varian kata tersebut mengindikasikan adanya asosiasi antara suatu varian vokal dengan muncul-tidaknya akhiran nasal? Untuk menjawab hal ini, kita perlu mengetahui bagaimana distribusi yang diharapkan muncul atas dasar kebetulan; frekuensi ini disebut dengan "frekuensi harapan" (expected frequency) $\left(\mathrm{F}_{\mathrm{e}}\right)($ Rajeg 2013; Rajeg \& Rajeg 2019a) (pada Tabel 2 berikut, frekuensi harapan $\left(\mathrm{F}_{\mathrm{e}}\right)$ ditampilkan dalam kurung). Sebaliknya, frekuensi riil yang diamati dari korpus disebut "frekuensi pengamatan" (observed frequency) $\left(\mathrm{F}_{\mathrm{o}}\right)$. 
Tabel 2 Frekuensi pengamatan (\& harapan) anggéle dan anggo dan ke(tidak)munculan akhiran nasal [n]

\begin{tabular}{|c|c|c|c|}
\cline { 2 - 3 } \multicolumn{1}{c|}{} & \multicolumn{2}{c|}{ AKHIRAN NASAL } & \multirow{2}{*}{ TOTAL } \\
\hline VOKAL AKHIR & Tidak & Ya & \\
\hline o & $169(104.44)$ & $256(320.56)$ & $\mathbf{4 2 5}$ \\
\hline e/é & $91(155.56)$ & $542(477.44)$ & $\mathbf{6 3 3}$ \\
\hline TOTAL & $\mathbf{2 6 0}$ & $\mathbf{7 9 8}$ & $\mathbf{1 0 5 8}$ \\
\hline \multicolumn{2}{|c|}{$X^{2}=88.427, d f=1, p<0.001$ Odds Ratio $=3.93$, Phi Coefficient $(\varphi)=0.28$}
\end{tabular}

$\mathrm{F}_{\mathrm{e}}$ masing-masing sel dihitung dengan mengalikan nilai total baris dan nilai total kolom untuk masingmasing sel tersebut; hasil perkalian ini kemudian dibagi dengan nilai total tabel keseluruhan (nilai di pojok kanan bawah dari Tabel 2 , yaitu 1058). ${ }^{7}$ Perbandingan frekuensi pengamatan $\left(\mathrm{F}_{\mathrm{o}}\right)$ dengan frekuensi harapan $\left(\mathrm{F}_{\mathrm{e}}\right)$ untuk masing-masing sel pada Tabel 2 menunjukkan bahwa anggéle lebih sering muncul (daripada yang diharapkan atas dasar kebetulan) dengan akhiran nasal (yaitu anggélen; $\mathrm{F}_{\mathrm{o}}>\mathrm{F}_{\mathrm{e}}$ ), sedangkan anggo lebih sering muncul daripada yang diharapkan tanpa akhiran nasal. Uji signifikansi akan menentukan tingkat penyimpangan $\mathrm{F}_{\mathrm{o}}$ dari $\mathrm{F}_{\mathrm{e}}$ tersebut dengan asumsi bahwa seharusnya tidak ada perbedaan distribusi antara varian vokal dan muncul-tidaknya akhiran nasal (atau dengan kata lain, distribusi akhiran nasal bersifat acak dan tidak berkaitan dengan akhiran vokal [é/e] dan [o]).

Hasil uji signifikansi dengan Chi-Square mengindikasikan bahwa distribusi yang diamati bukanlah suatu kebetulan, yaitu terdapat perbedaan yang secara statistik sangat signifikan antara frekuensi pengamatan dengan apa yang diharapkan dalam hal tidak adanya kaitan antara akhiran vokal dengan muncul-tidaknya akhiran nasal pada varian anggéle dan anggo $\left(X^{2}=88.427, d f=1, p<0.001\right)$. Dengan kata lain, kita menemukan asosiasi signifikan antara varian vokal dan muncul-tidaknya akhiran nasal pada anggéle dan anggo. Nilai Odds Ratio (Rajeg 2020b; Levshina 2015: 208) untuk Tabel 2 menunjukkan bahwa terdapat peluang 3.93 lebih tinggi untuk mengamati anggo (dibandingkan anggéle) muncul tanpa akhiran nasal dibandingkan dengan akhiran nasal. Arah dan taraf asosiasi tiap-tiap sel ditunjukkan secara lebih intuitif pada Gambar 3, yang disebut Bagan Asosiasi (Association Plot).

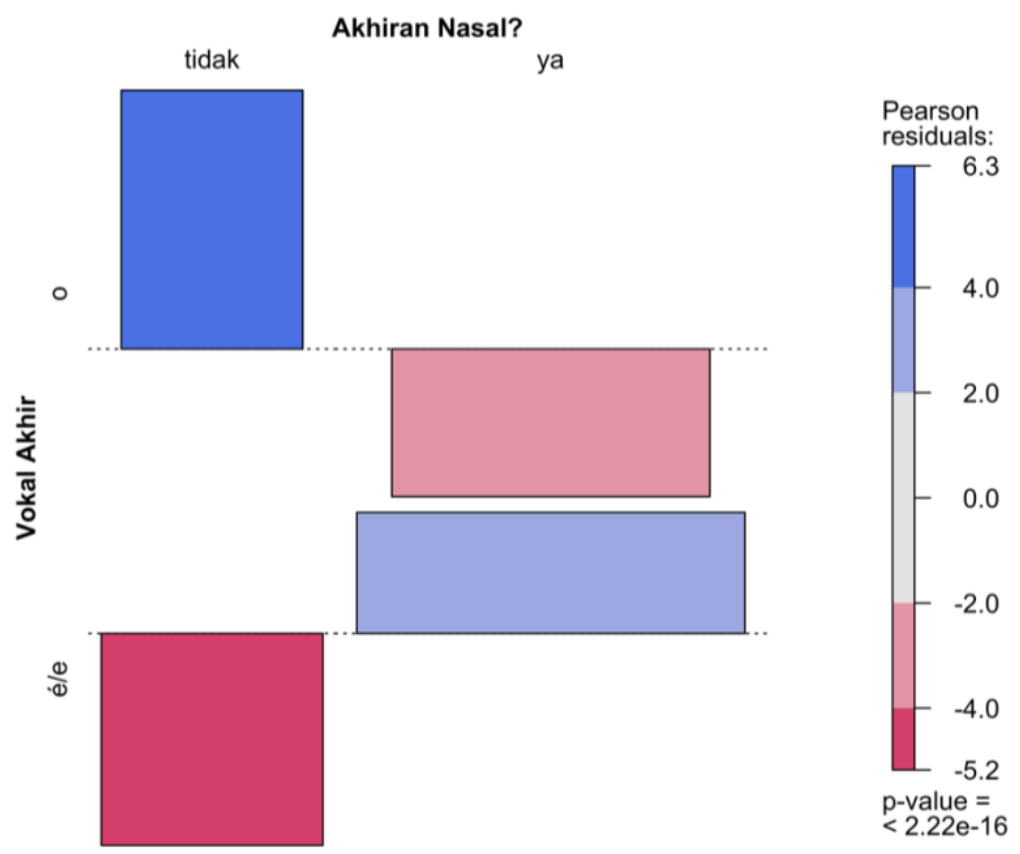

Gambar 3 Bagan Asosiasi antara Vokal Akhir dan muncul-tidaknya akhiran nasal pada bentuk dasar

\footnotetext{
${ }^{7}$ Sebagai contoh, frekuensi harapan $\left(\mathrm{F}_{\mathrm{e}}\right)$ untuk nilai dalam sel pada baris $o$ dan kolom Tidak (yaitu frekuensi kemunculan anggo tanpa akhiran nasal ( $\mathrm{F}_{\mathrm{o}}$ ): 169) dihitung dengan mengalikan 260 (total kolom Tidak) dengan 425 (total baris $o$ ) dan membagi hasil perkalian ini dengan total tabel, yaitu 1058: $(260 * 425) / 1058=104.44$.
} 
Varian dengan vokal akhir [o], yaitu anggo, berasosiasi positif dan kuat dengan kemunculannya tanpa akhiran nasal (ditunjukkan oleh persegi biru menjulang ke atas dan gelapnya warna biru persegi tersebut) dan berasosiasi negatif dengan akhiran nasal (persegi merah mudah yang menggantung ke bawah). Asosiasi sebaliknya ditunjukkan oleh varian dengan vokal akhir [é/e], yaitu anggé/e, yang berasosiasi positif dengan kemunculannya bersama akhiran nasal. Yang dapat disimpulkan dari pembahasan varian bentuk dasar anggéle dan anggo ini adalah sebagai berikut: meskipun distribusi riil yang diamati pada Tabel 1 bukanlah suatu kebetulan, dan Gambar 3 menunjukkan asosiasi antara variabel VOKAL AKHIR dan AKHIRAN NASAL, efek perbedaan distribusi tersebut secara keseluruhan (misalnya, efek secara praktis) kecil (Phi Coefficient $(\varphi)=0.28)$ (Levshina 2015: 209).

Pertanyaan yang muncul selanjutnya adalah apakah asosiasi antara varian vokal dengan ke(tidak)munculan akhiran nasal pada bentuk dasar anggéle dan anggo diamati juga pada bentuk turunannya? Untuk menjawab pertanyaan ini, frekuensi varian vokal dengan muncul-tidaknya akhiran nasal pada bentuk turunan dikumpulkan (Tabel 3) dan dianalisis dengan uji signifikansi Chi-Square. Bentuk turunan tersebut di antaranya adalah penambahan awalan diatesis, seperti maanggéle/o $(n)$, nganggélelo $(n), k(a / e)$ anggélelo $(n), m(e / a)$ panganggélelo( $n)$, dan turunannya sebagai nomina, seperti $p(a / e) n g a n g g e ́ l e l o(n)$.

Tabel 3 Frekuensi pengamatan (\& harapan) bentuk turunan anggélelo dan ke(tidak)munculan akhiran nasal [n]

\begin{tabular}{|c|c|c|c|}
\cline { 2 - 3 } \multicolumn{1}{c|}{} & \multicolumn{2}{c|}{ AKHIRAN NASAL } & \multirow{2}{*}{ TOTAL } \\
\hline VOKAL AKHIR & Tidak & Ya & \\
\hline o & $199(104.57)$ & $72(166.43)$ & $\mathbf{2 7 1}$ \\
\hline e/é & $374(468.43)$ & $840(745.57)$ & $\mathbf{1 2 1 4}$ \\
\hline TOTAL & $\mathbf{5 7 3}$ & $\mathbf{9 1 2}$ & $\mathbf{1 4 8 5}$ \\
\hline
\end{tabular}

$$
X^{2}=169.86, d f=1, p<0.001, \text { Odds Ratio }=6.2, \text { Phi Coefficient }(\varphi)=0.34
$$

Hasil uji signifikansi Chi-Square pada data bentuk turunan dari anggéle/o juga menariknya menunjukkan asosiasi yang sangat signifikan antara varian vokal dan tendensi ke(tidak)munculan akhiran nasal $[\mathrm{n}]$, meskipun efeknya juga kecil (Phi Coefficient $(\varphi)=0.34)$, seperti halnya dengan bentuk dasar. Arah asosiasi yang ditemukan pada bentuk dasar dipertahankan pada bentuk turunan; hal ini dapat dilihat pada Gambar 4 yang mirip dengan Gambar 3, dengan perbedaan yang terlihat pada semakin kuatnya asosiasi negatif akhiran vokal [o] dengan kemunculan akhiran [n] (ditunjukkan dengan warna merah gelap). Kita juga melihat bahwa peluang tidak munculnya akhiran nasal untuk varian vokal [o] pada bentuk turunan 6.2 lebih tinggi dibandingkan dengan munculnya akhiran nasal.

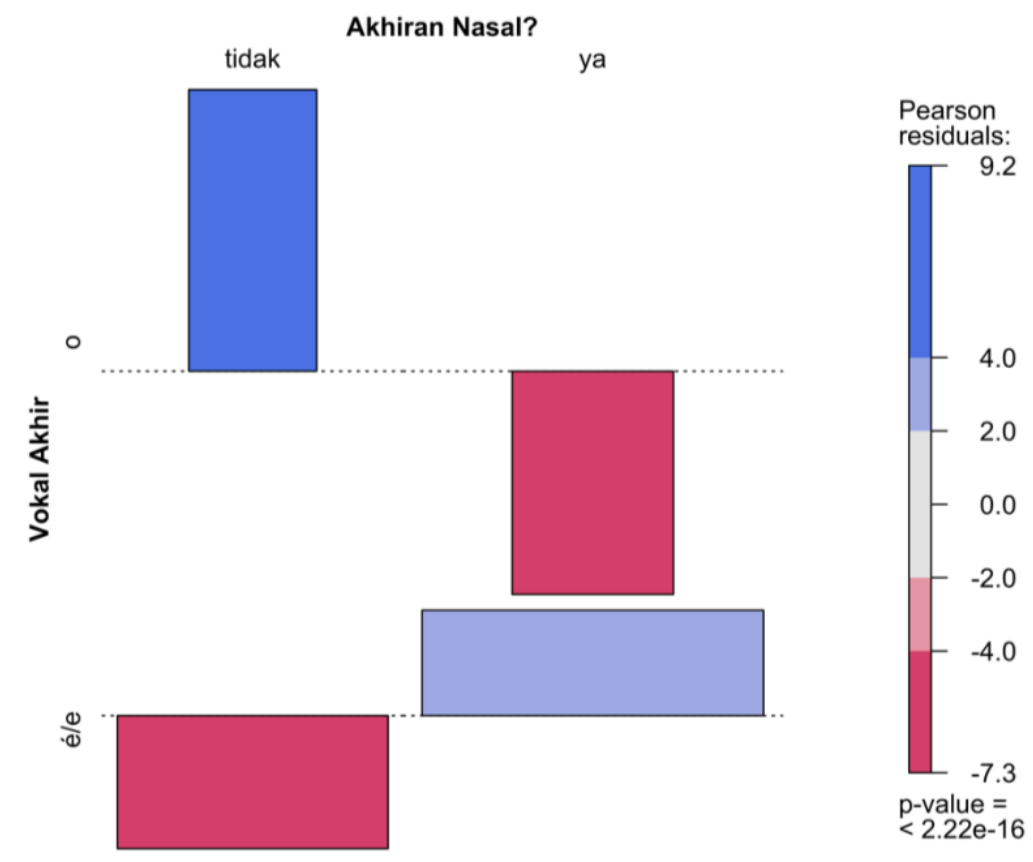

Gambar 4 Bagan Asosiasi antara Vokal Akhir dan muncul-tidaknya akhiran nasal pada bentuk turunan 
Hasil analisis untuk rumusan masalah pertama menunjukkan bahwa terdapat asosiasi yang sangat signifikan untuk varian kata bermakna sama, yaitu anggéle $(n)$ dan anggo $(n)$ 'pakai; gunakan' terkait variasi fonologis/ortografis dari varian kata tersebut. Dalam hal ini, varian bentuk dasar anggéle dan bentuk turunannya, sama-sama berasosiasi positif dan kuat, dalam pemakaian varian tersebut, dengan akhiran nasal [n] (yaitu anggélen). Sebaliknya, bentuk dasar anggo, beserta bentuk turunannya, berasosiasi negatif, dalam pemakaian varian tersebut, dengan akhiran nasal [n] (lihat Gambar 3 dan Gambar 4).

\section{Kolokat khas untuk anggéle(n) dan anggo(n)}

Rumusan masalah kedua dari makalah ini adalah konteks yang mencirikan ragam/tingkat bahasa Bali dari anggéle/o(n). Konteks diukur dan dioperasionalkan melalui kolokat khas dari pemakaian bentuk dasar anggéle/o( $n)$ dalam korpus. Ruang yang diberikan untuk makalah ini menghalangi penulis mengulas secara lebih rinci teknik Analisis Kolokat Khas (Distinctive Collocate Analysis [DCA]) yang digunakan untuk tujuan kali ini (tetapi lihat Gries \& Stefanowitsch 2004; dan Gries 2013 untuk ulasan awal. Lihat Rajeg \& Rajeg 2019b untuk ulasan berbahasa Indonesia). Secara ringkas, penghitungan statistik kekhasan kolokat dalam DCA mengikuti rancangan tabel dua dimensi yang telah kita lihat seperti pada Tabel 1, dan membandingkan frekuensi pengamatan (dengan frekuensi harapan) suatu kolokat terhadap dua kata/konstruksi yang mirip secara semantis. Perbandingan frekuensi pengamatan dan frekuensi harapan, serta uji signifikansi dengan Fisher-Yates Exact test (FYE) yang terdapat dalam DCA, dapat menentukan kekhasan suatu kolokat terhadap salah satu dari dua kata/konstruksi yang dibandingkan, dalam hal ini anggéle( $n)$ dan anggo(n).

Sebagai contoh, perhatikan Tabel 4, yang menampilkan frekuensi-frekuensi yang dibutuhkan untuk melakukan DCA, di antaranya frekuensi kemunculan kolokat pipis 'uang' (baris) di lingkup tiga kata sebelah kanan dan kiri dari kata target anggéle(n) dan anggo(n) (kolom); frekuensi harapan ditampilkan dalam kurung dan dicetak miring.

Tabel 4 Distribusi pipis 'uang' sebagai kolokat dari anggéle(n) dan anggo(n)

\begin{tabular}{|c|c|c|c|}
\cline { 2 - 3 } \multicolumn{1}{c|}{} & \multicolumn{2}{c|}{ KATA TARGET } & \multirow{2}{*}{ TOTAL } \\
\hline KOLOKAT & anggéle(n) & anggo(n) & 33 \\
\hline pipis 'uang' & $4(20.48)$ & $29(12.51)$ & $\mathbf{5 4 4 2}$ \\
\hline kolokat lainnya & $3395(3378.51)$ & $2047(2063.48)$ & $\mathbf{5 4 7 5}$ \\
\hline TOTAL & $\mathbf{3 3 9 9}$ & $\mathbf{2 0 7 6}$ & \\
\hline
\end{tabular}

Dapat diperhatikan pada Tabel 4 bahwa pipis, ragam bahasa Bali kasar untuk 'uang' (ragam bahasa Bali halus/sopan adalah jinah 'uang'), muncul lebih sering dari yang diharapkan dengan ragam kasar anggo $(n)$ (dibandingkan dengan anggéle $(n)$ ). Apakah penyimpangan distribusi pengamatan dan harapan ini signifikan secara statistik? Dengan memasukkan frekuensi pengamatan dari keempat sel pada Tabel 4 ke dalam uji signifikansi dengan FYE, kita mendapatkan nilai probabilitas yang sangat kecil $\left(p_{\mathrm{FYE}}=3.64 \mathrm{E}-09^{8}\right.$, yaitu $\left.p_{\mathrm{FYE}}<0.001\right)$ untuk menganggap bahwa distribusi, dan selisih frekuensi pengamatan atas frekuensi harapan, pada Tabel 4 adalah suatu kebetulan. Dalam DCA, nilai probabilitas ini diubah ke dalam bentuk logaritma negatif berbasis nilai 10, yang disebut dengan "daya kekhasan" (distinctiveness) atau "daya kolokasi" (collocation strength [CollStr]), sehingga dapat dipahami secara lebih intuitif (lihat penjelasannya pada Stefanowitsch \& Gries 2005). Semakin tinggi nilai CollStr untuk suatu kolokat terhadap salah satu dari dua kata target yang dibandingkan, semakin kuat kekhasan kolokat tersebut dengan kata target yang dimaksud. Rentang nilai CollStr signifikan ditunjukkan oleh CollStr $>1.30103$ (untuk $p_{\text {FYE }}<0.05$ ), CollStr $>2$ ( $p_{\text {FYE }}<0.01$ ), dan CollStr $>3$ ( $\left.p_{\mathrm{FYE}}<0.001\right)$. Nilai CollStr untuk Tabel 4 adalah 8.44.

Dari sudut pandang DCA, hasil FYE pada Tabel 4 menunjukkan bahwa pipis 'uang' adalah "kolokat khas signifikan" untuk anggo(n) (karena muncul bukan secara kebetulan lebih sering daripada yang diharapkan dengan anggo(n)) dibandingkan dengan anggéle( $n)$. Analisis statistik serupa mesti diulang terhadap semua kolokat yang muncul dalam lingkup tiga kata sebelah kanan dan kiri dari kedua kata target dalam korpus, sehingga nantinya kolokat tersebut dapat diranking berdasarkan kekhasan dan

\footnotetext{
${ }^{8}$ Representasi lain dari format ilmiah probabilitas 3.64E-09 adalah 0.000000003644631, sehingga $p<0.001$.
} 
signifikansinya terhadap salah satu dari dua kata yang dibandingkan kali ini (perhatikan Tabel 5 dan Tabel 6 berikut). Data ranking kolokat khas tersebut dapat diinterpretasikan secara kualitatif untuk melihat perbedaan fungsional/semantis di antara dua kata yang mirip secara semantis. Dalam makalah ini, perbedaan fungsional dilihat melalui ragam tingkatan bahasa Bali yang dicerminkan oleh kolokat khas untuk anggéle $(n)$ dan anggo(n). Pengelompokan ragam tingkatan bahasa Bali ini diperoleh dari kamus daring BASABali Wiki (https://dictionary.basabali.org/Dictionary).

Tabel 5 Tiga puluh kolokat khas signifikan untuk anggo(n) $(p<0.01$; CollStr $>2)$

\begin{tabular}{|c|c|c|c|c|c|c|}
\hline Kolokat & Gloss & Ragam9 & $\mathrm{N}_{\text {anggo(n) }}{ }^{10}$ & $\mathbf{N}_{\text {anggéle(n) }}$ & $p_{\text {Fisher-Yates Exact }}$ & CollStr \\
\hline dadi & bisa; dapat & andap & 38 & 1 & $1.98 \mathrm{E}-15$ & 14.7 \\
\hline ané & yang & andap_kasar & 43 & 3 & $2.29 \mathrm{E}-15$ & 14.64 \\
\hline meli & membeli & andap_kasar & 33 & 1 & $2.33 \mathrm{E}-13$ & 12.63 \\
\hline $\operatorname{sing}$ & tidak & andap & 25 & 0 & $2.70 \mathrm{E}-11$ & 10.57 \\
\hline lakar & akan & andap_kasar & 28 & 2 & $2.54 \mathrm{E}-10$ & 9.59 \\
\hline apa & apa & andap & 22 & 0 & $5.06 \mathrm{E}-10$ & 9.3 \\
\hline pis & uang & andap & 21 & 0 & $1.34 \mathrm{E}-09$ & 8.87 \\
\hline$a d a$ & ada & andap_kasar & 20 & 0 & $3.57 \mathrm{E}-09$ & 8.45 \\
\hline pipis & uang & andap & 29 & 4 & 3.64E-09 & 8.44 \\
\hline ento & itu & andap_kasar & 21 & 1 & $1.89 \mathrm{E}-08$ & 7.72 \\
\hline ngalih & mencari & andap & 18 & 0 & $2.51 \mathrm{E}-08$ & 7.6 \\
\hline apang & sehingga; supaya & andap_kasar & 18 & 1 & $3.06 \mathrm{E}-07$ & 6.51 \\
\hline tusing & tidak & andap & 15 & 0 & 4.67E-07 & 6.33 \\
\hline$d i$ & di & mider & 14 & 0 & $1.24 \mathrm{E}-06$ & 5.91 \\
\hline gén & saja & andap & 12 & 0 & $8.66 \mathrm{E}-06$ & 5.06 \\
\hline keneh & pikiran & andap_kasar & 13 & 1 & $2.97 \mathrm{E}-05$ & 4.53 \\
\hline mayah & membayar & andap & 13 & 1 & $2.97 \mathrm{E}-05$ & 4.53 \\
\hline tiang & saya & alus & 26 & 11 & $6.31 \mathrm{E}-05$ & 4.2 \\
\hline nyidayang & mampu & andap & 9 & 0 & $1.60 \mathrm{E}-04$ & 3.8 \\
\hline suba & sudah & andap & 9 & 0 & $1.60 \mathrm{E}-04$ & 3.8 \\
\hline tongos & tempat & andap_kasar & 11 & 1 & $1.80 \mathrm{E}-04$ & 3.75 \\
\hline ngaé & membuat & andap_kasar & 10 & 1 & $4.38 \mathrm{E}-04$ & 3.36 \\
\hline tuah & hanya & andap_kasar & 9 & 1 & 0.00105736 & 2.98 \\
\hline carik & sawah & andap & 7 & 0 & 0.00111988 & 2.95 \\
\hline liu & banyak & andap & 7 & 0 & 0.00111988 & 2.95 \\
\hline mesuang & mengeluarkan & andap & 7 & 0 & 0.00111988 & 2.95 \\
\hline né & ini & andap_kasar & 7 & 0 & 0.00111988 & 2.95 \\
\hline yéh & air & andap & 7 & 0 & 0.00111988 & 2.95 \\
\hline ngelah & memiliki & andap & 11 & 3 & 0.002342 & 2.63 \\
\hline$b a$ & sudah & andap_kasar & 8 & 1 & 0.00253138 & 2.6 \\
\hline
\end{tabular}

Berdasarkan data pada Tabel 5, varian anggo(n) secara kuat diasosiasikan dengan kolokat yang dalam BASABali Wiki dimasukkan ke dalam ragam andap, yaitu ragam percakapan sehari-hari. Ragam

\footnotetext{
${ }^{9}$ Pengelompokan kolokat berdasarkan ragam bahasa Bali alus, kasar, dan andap 'akrab; bahasa sehari-hari' didasari atas entri kolokat tersebut pada BASABali Wiki. Sumber lain pengelompokan tersebut akan disebutkan secara eksplisit.

${ }^{10} \mathrm{~N}_{\text {anggo(n) }}$ dan $\mathrm{N}_{\text {anggéle( } n)}$ menunjukkan frekuensi pengamatan kolokat dalam lingkup tiga kata di sekitar anggo(n) dan/atau anggéle(n).
} 
andap_kasar mengindikasikan bahwa kata tersebut dimasukkan ke dalam dua ragam oleh BASABali Wiki, yaitu andap dan kasar. Profil berbeda ditunjukkan oleh anggéle(n), yang tampak lebih kuat berasosiasi dengan kolokat yang mencerminkan ragam alus, dan pada taraf tertentu, juga dengan ragam andap (Tabel 6).

Tabel 6 Tiga puluh kolokat khas signifikan untuk anggéle $(n)(p<0.01 ;$ CollStr $>2)$

\begin{tabular}{|c|c|c|c|c|c|c|}
\hline Kolokat & Gloss & Ragam & $\mathbf{N}_{\text {anggo(n) }}$ & $\mathbf{N}_{\text {anggéle(n) }}$ & $p_{\text {Fisher-Yates Exact }}$ & CollStr \\
\hline sané & yang & alus mider & 1 & 116 & $2.08 \mathrm{E}-23$ & 22.68 \\
\hline ring & di & alus mider & 0 & 53 & $9.12 \mathrm{E}-12$ & 11.04 \\
\hline punika & itu; begitu & alus mider & 2 & 54 & $1.35 \mathrm{E}-09$ & 8.87 \\
\hline becik & baik & alus mider & 0 & 35 & 5.31E-08 & 7.28 \\
\hline prasida & bisa; mampu & alus mider & 0 & 30 & $5.86 \mathrm{E}-07$ & 6.23 \\
\hline dados & boleh; mengapa & alus mider & 0 & 29 & $9.47 \mathrm{E}-07$ & 6.02 \\
\hline mangda & agar; supaya & alus mider & 0 & 27 & $2.47 \mathrm{E}-06$ & 5.61 \\
\hline patut & benar; cocok; patut & alus mider & 2 & 36 & $3.67 \mathrm{E}-06$ & 5.44 \\
\hline nénten & tidak & alus mider & 0 & 26 & 3.99E-06 & 5.4 \\
\hline pisan & amat; sangat & alus mider & 0 & 26 & 3.99E-06 & 5.4 \\
\hline ngrereh & mencari & alus mider & 0 & 25 & $6.45 \mathrm{E}-06$ & 5.19 \\
\hline genah & tempat & andap & 0 & 23 & $1.68 \mathrm{E}-05$ & 4.77 \\
\hline pinaka & sebagai & andap & 0 & 23 & $1.68 \mathrm{E}-05$ & 4.77 \\
\hline puniki & ini; begini & alus mider & 0 & 23 & $1.68 \mathrm{E}-05$ & 4.77 \\
\hline prabéa & biaya & andap & 0 & 20 & $7.08 \mathrm{E}-05$ & 4.15 \\
\hline titiang & saya & alus sor & 0 & 20 & $7.08 \mathrm{E}-05$ & 4.15 \\
\hline nyanggra & melaksanakan & andap & 0 & 19 & $1.14 \mathrm{E}-04$ & 3.94 \\
\hline wantah & hanya; saja & andap & 1 & 22 & $2.55 \mathrm{E}-04$ & 3.59 \\
\hline wénten & ada & alus mider & 0 & 17 & $2.98 \mathrm{E}-04$ & 3.53 \\
\hline jagi & akan & andap & 0 & 16 & $4.80 \mathrm{E}-04$ & 3.32 \\
\hline angga & badan & andap & 0 & 15 & 7.75E-04 & 3.11 \\
\hline taler & juga & andap & 0 & 15 & 7.75E-04 & 3.11 \\
\hline bali & bali & NA & 1 & 19 & $9.41 \mathrm{E}-04$ & 3.03 \\
\hline pacang & akan & andap & 0 & 14 & 0.00125061 & 2.9 \\
\hline sarana & sarana & andap & 1 & 17 & 0.00222294 & 2.65 \\
\hline utawi & atau & andap & 3 & 22 & 0.00428201 & 2.37 \\
\hline ipun & dia & alus sor & 0 & 11 & 0.00524769 & 2.28 \\
\hline lan & dan & andap & 12 & 44 & 0.006267 & 2.2 \\
\hline nagingin & mengisi & andap & 0 & 10 & 0.00846227 & 2.07 \\
\hline$r i$ & di; pada & alus mider & 0 & 10 & 0.00846227 & 2.07 \\
\hline
\end{tabular}

Pengamatan menarik lainnya yang dapat diulas dari kedua luaran DCA ini adalah melihat ketimpangan frekuensi kemunculan untuk kolokat dengan arti yang sama namun berbeda dari ragamnya. Salah satu contohnya, kolokat dengan arti 'mencari' bisa muncul dengan kedua varian, namun varian andap untuk konsep semantis ini, yaitu ngalih 'mencari', hanya digunakan dengan anggo(n) dan tidak pernah sekalipun dengan anggéle $(n)$; sebaliknya ngrereh 'mencari' adalah varian alus yang hanya digunakan oleh anggéle( $n)$ dan tidak pernah dengan anggo(n).

Selanjutnya, kita dapat menjumlahkan nilai CollStr masing-masing ragam tingkatan bahasa dari kolokat khas tersebut untuk melihat daya kekhasan total ragam tersebut untuk tiap-tiap varian, lalu 
memvisualisasikannya untuk pengamatan yang lebih intuitif (perhatikan Gambar 5) (teknik ini terinspirasi dari kajian Wulff, Stefanowitsch \& Gries 2007).

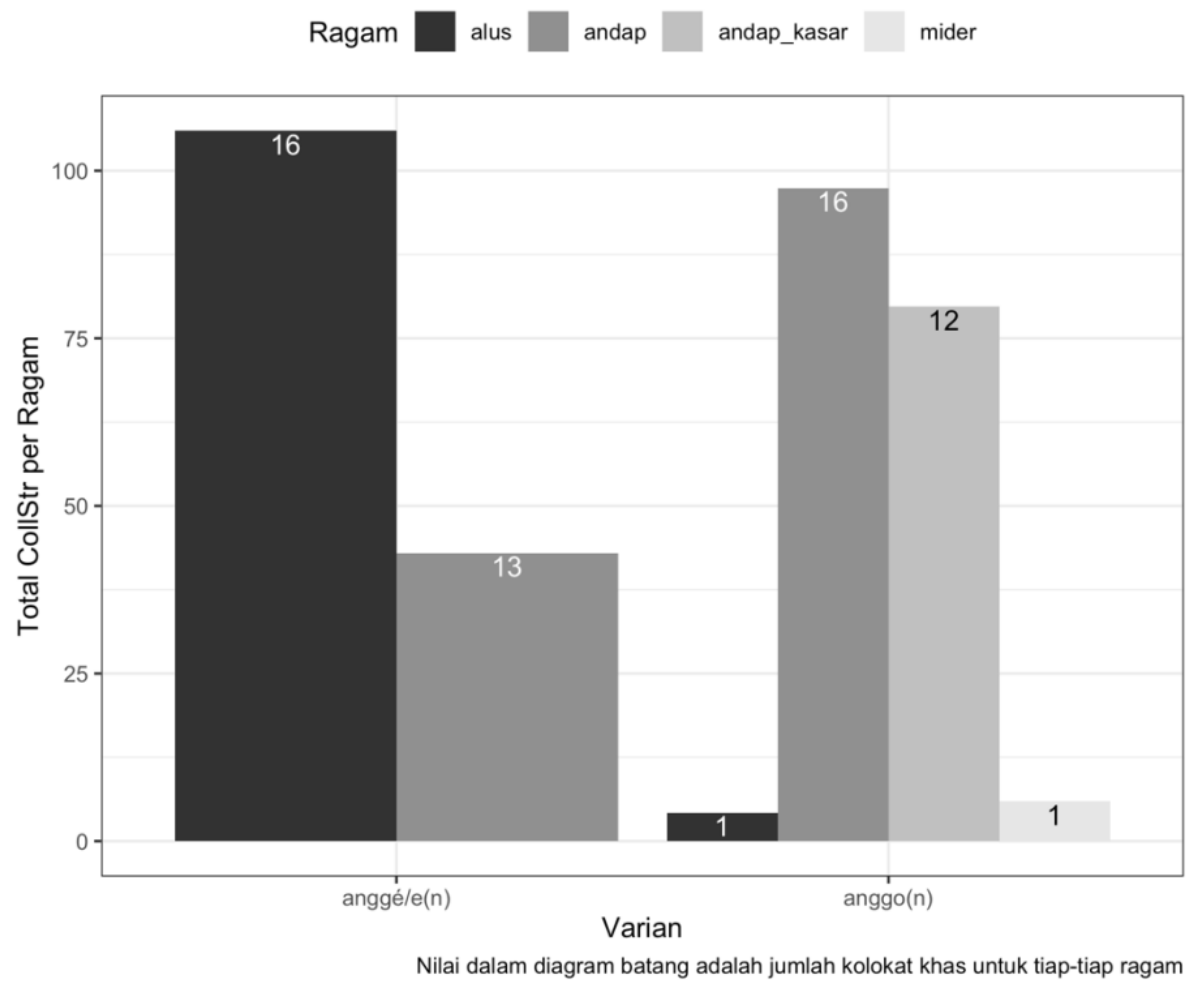

Gambar 5 Total nilai Data Kekhasan CollStr dan jumlah kolokat khas untuk masing-masing ragam per varian

Gambar 5 dengan jelas menunjukkan bahwa ragam alus secara kuat diasosiasikan dengan varian anggéle( $n)$ jika membandingkan baik total daya kekhasan CollStr dan jumlah kolokat khas ragam alus ini untuk anggéle $(n)$ dengan ragam yang sama untuk anggo(n), yang hanya memiliki satu kolokat khas ragam alus. Meskipun anggéle ( $n$ ) juga dapat diasosiasikan dengan ragam percakapan sehari-hari (yaitu andap), ragam ini lebih dominan diasosiasikan dengan anggo(n), baik dari total nilai CollStr untuk andap dan andap_kasar dan jumlah kolokat khas kedua ragam ini. Perpaduan informasi kualitatif dan kuantitatif berdasarkan data korpus seperti ini dapat digunakan untuk memperkaya deskripsi leksikografis suatu kata dalam kamus, khususnya BASABali Wiki, yang menjadi sumber kamus makalah ini.

\section{Simpulan}

Makalah ringkas ini telah menampilkan suatu studi kasus linguistik korpus kuantitatif terhadap pola variasi ortografis kata yang mirip secara semantis dan konteks pemakaiannya (dalam hal ini konteks kolokasi). Analisis dilakukan terhadap pasangan varian verba bahasa Bali dasar anggéle( $n)$ dan anggo(n) yang sama-sama berarti 'pakai; gunakan'. Rumusan masalah pertama makalah ini adalah apakah ke(tidak)munculan akhiran nasal [n] di kedua varian dengan perbedaan vokal akhir [é/e] dan [o] tersebut adalah suatu kebetulan? Makalah ini menemukan pola asosiasi yang tidak bisa dikatakan bersifat acak/manasuka secara statistik antara muncul-tidaknya akhiran nasal dan kedua varian yang berbeda vokal akhirnya, baik dalam bentuk dasar ataupun turunan dari verba anggéle $(n)$ dan anggo(n). Kami menemukan bahwa varian dengan vokal akhir [é/e] (yaitu anggéle) berasosiasi positif dengan munculnya akhiran nasal, sedangkan varian dengan vokal akhir [o] (yaitu anggo) berasosiasi positif dengan tidak munculnya akhiran nasal. Tanpa analisis kuantitatif seperti yang ditampilkan pada makalah ini, pola asosiasi dari varian yang tampaknya acak secara kasat mata tidak dapat diungkap.

Rumusan masalah kedua berkaitan dengan konteks kolokasi yang dapat mencerminkan ragam tingkatan bahasa Bali yang dipicu oleh anggéle $(n)$ dan anggo(n). Tujuan rumusan masalah ini (dan 
juga masalah sebelumnya) diharapkan dapat menjadi model pemutakhiran dan pengayaan deskripsi leksikografis berdasarkan bukti korpus untuk suatu kata, khususnya anggéle $(n)$ yang entrinya di BASABali Wiki masih kosong. Secara ringkas, teknik kuantitatif Analisis Kolokat Khas yang digunakan untuk rumusan masalah kedua menunjukkan adanya perbedaan ciri kontekstual (berdasarkan data kolokat khas) ragam tingkatan bahasa Bali untuk anggé/e( $n)$ dan anggo(n) (lihat Tabel 5, Tabel 6, dan Gambar 5): anggo(n) secara dominan berasosiasi dengan ragam tingkatan bahasa Bali andap ('bahasa sehari-hari'), sedangkan anggéle $(n)$ berasosiasi kuat dengan ragam tingkatan bahasa Bali alus ('halus').

\section{Daftar pustaka}

Gries, Stefan Th. 2013. Corpus linguistics: Quantitative methods. In Carol A. Chapelle (ed.), The Encyclopedia of Applied Linguistics, 1-5. Chichester, West Sussex, UK: Blackwell Publishing Ltd. https://doi.org/10.1002/9781405198431.wbeal0258.

Gries, Stefan Th. \& Anatol Stefanowitsch. 2004. Extending collostructional analysis: A corpus-based perspective on "alternations." International Journal of Corpus Linguistics 9(1). 97-129.

Hopper, Paul J. \& Elizabeth Closs Traugott. 2003. Grammaticalization (Cambridge Textbooks in Linguistics). 2nd edn. Cambridge: Cambridge University Press.

Levshina, Natalia. 2015. How to do Linguistics with R: Data exploration and statistical analysis. John Benjamins Publishing Company. https://doi.org/10.1075/z.195.

R Core Team. 2020. R: A language and environment for statistical computing. Manual. Vienna, Austria. https://www.R-project.org/.

Rajeg, Gede Primahadi Wijaya. 2020a. Konsep Uji Signifikansi dengan Chi-Square untuk Linguistik Korpus. Vol. 1. https://www.youtube.com/watch?v=fR3lmVXbQhM (7 December, 2020).

Rajeg, Gede Primahadi Wijaya. 2020b. Konsep Odds Ratio untuk Linguistik Korpus. Vol. 1. https://www.youtube.com/watch?v=ZErL7uORTPY (9 December, 2020).

Rajeg, Gede Primahadi Wijaya \& I Made Rajeg. 2019a. Pemahaman kuantitatif dasar dan penerapannya dalam mengkaji keterkaitan antara bentuk dan makna. Linguistik Indonesia 37(1). 13-31. https://doi.org/10.26180/5c6e1160b8d8a.

Rajeg, Gede Primahadi Wijaya \& I Made Rajeg. 2019b. Analisis Koleksem Khas dan potensinya untuk kajian kemiripan makna konstruksional dalam Bahasa Indonesia. In I Nengah Sudipa (ed.), ETIKA BAHASA Buku persembahan menapaki usia pensiun: I Ketut Tika, vol. 1, 6583. Denpasar, Bali, Indonesia: Swasta Nulus. https://doi.org/10.26180/5bf4e49ea1582. https://osf.io/preprints/inarxiv/uwzts/ (30 January, 2019).

Rajeg, Gede Primahadi Wijaya \& I Made Rajeg. 2020. Data dan kode pemrograman R untuk kajian linguistik korpus kuantitatif terhadap variasi ortografis dan kontekstual untuk verba Bahasa Bali anggéle(n) dan anggo(n). figshare. https://doi.org/10.6084/m9.figshare.13350779. https://github.com/gederajeg/anggen.

Rajeg, I Made. 2013. Metafora emosi Bahasa Indonesia. Denpasar, Bali, Indonesia: Universitas Udayana Disertasi doktoral. https://doi.org/10.6084/m9.figshare.7886180.

Stefanowitsch, Anatol \& Stefan Th. Gries. 2005. Covarying collexemes. Corpus Linguistics and Linguistic Theory 1(1). 1-43.

Wulff, Stefanie, Anatol Stefanowitsch \& Stefan Th. Gries. 2007. Brutal Brits and persuasive Americans: Variety-specific meaning construction in the into-causative. In Günter Radden, Klaus-Michael Köpcke, Thomas Berg \& Peter Siemund (eds.), Aspects of Meaning Construction, 265-281. Amsterdam: John Benjamins Publishing Company. 